\title{
Agricultural tractor performance with different wheel and tire configurations
}

\section{Desempenho de trator agrícola com diferentes configurações de rodados e pneus}

\author{
Marcelo Silveira de FARIAS ${ }^{1}$; José Fernando SCHLOSSER²; Alexandre RUSSINI³; Giácomo Müller NEGRI; \\ Leonardo CASALI ${ }^{4}$ \\ 1 "Autor para correspondência”. Doutor em Engenharia Agrícola. Universidade Federal de Santa Maria, Campus de Frederico \\ Westphalen, Departamento de Ciências Agronômicas e Ambientais. Linha 7 de Setembro, s/n, BR 386 km 40, CEP: $98400-$ \\ 000, Frederico Westphalen, RS. silveira farias@hotmail.com \\ ${ }^{2}$ Doutor em Engenharia Agrícola. Universidade Federal de Santa Maria. josefernandoschlosser@gmail.com \\ ${ }^{3}$ Doutor em Engenharia Agrícola. Universidade Federal do Pampa, Campus Itaqui. alexandrerussini@unipampa.edu.br \\ ${ }^{4}$ Alunos do curso de Agronomia. Universidade Federal de Santa Maria. gm.negri14@gmail.com; \\ leonardo.casali@yahoo.com.br
}

Recebido em: 07-08-2018; Aceito em: 05-11-2018

\begin{abstract}
This study evaluates the performance of an agricultural tractor with a maximum power of $92.4 \mathrm{~kW}(125.6 \mathrm{hp})$, equipped with different wheel and tire configurations. The experiment was carried out in the field, with a randomized block design in a trifactorial scheme, with two wheel and tire configurations (double wheel and diagonal tire; single wheel and radial tire), three mass-power ratios $\left(61,67\right.$, and $\left.74 \mathrm{~kg} \mathrm{~kW}^{-1}\right)$, and three levels of partial loads imposed on the drawbar $(24,27$, and $36 \mathrm{kN})$, on firm soil covered with vegetation. The data were recorded by means of electronic instrumentation installed in the tractor. The results indicate that the double wheel and diagonal tire configuration showed better performance regarding traction force, traction power, and traction efficiency, as well as lower specific fuel consumption. In turn, the simple wheel and radial tire configuration showed the lowest values of driving wheel slipping. The best traction performance was obtained with the mass-power ratio of 67 $\mathrm{kg} \mathrm{kW}^{-1}$ for the double wheel and diagonal tire configuration, and $61 \mathrm{~kg} \mathrm{~kW}^{-1}$ for the single wheel and radial tire configuration.
\end{abstract}

Additional keywords: soil-machine interaction; traction efficiency; volumetric fuel consumption.

\section{Resumo}

Objetivou-se avaliar o desempenho de um trator agrícola com potência máxima de 92,4 kW (125,6 cv), equipado com diferentes configurações de rodados e pneus. O experimento foi realizado em campo, com delineamento blocos ao acaso, em arranjo trifatorial, sendo avaliadas duas configurações de rodados e pneus (rodado duplo e pneu diagonal; e rodado simples e pneu radial), três relações massa/potência $\left(61,67\right.$ e $\left.74 \mathrm{~kg} \mathrm{~kW}^{-1}\right)$, e três níveis de cargas parciais impostas na barra de tração $(24,27$ e $36 \mathrm{kN})$, em solo firme com cobertura vegetal. Os dados foram registrados por meio de instrumentação eletrônica instalada no trator. Os resultados indicam que a configuração rodado duplo e pneu diagonal apresentou melhor desempenho referente à força de tração, potência de tração e eficiência de tração, bem como menor consumo específico de combustível. Por sua vez, a configuração rodado simples e pneu radial obteve os menores valores de patinamento das rodas motrizes. Quando o trator foi equipado com rodado duplo e pneu diagonal, o melhor desempenho em tração foi obtido para a relação massa/potência de $67 \mathrm{~kg} \mathrm{~kW}^{-1}$, enquanto com rodado simples e pneu radial foi de $61 \mathrm{~kg} \mathrm{~kW}^{-1}$.

Palavras-chave adicionais: consumo volumétrico de combustível; eficiência de tração; interação solo-máquina.

\section{Introduction}

In the last decades, agricultural mechanization has intensified, resulting in an increased load applied to the soil by agricultural machinery (Yavuzcan et al., 2005), in which the effects of soil-machine interaction may be negative for tractor performance (Fiorese et al., 2015). Toledo et al. (2010) argue that mechanized agricultural operations should be planned for an increased profitability in the field; therefore, mechanization is considered a key factor in reducing production costs (Peloia \& Milan, 2010).

Zoz \& Grisso (2003) highlight that the main point to be observed in tractors is drawbar performance, which, according to Monteiro et al. (2013), can be a parameter used to compare and evaluate agricultural tractors. When assessing drawbar force, tractor travel speed, and calculating the available drawbar power, it is possible to detect the working conditions that offer greater and less efficiency for the machine set (Jasper et al., 2016).

Tractor drawbar performance can vary de- 
pending on the conditions of the work surface, such as texture, humidity, and coverage, as well as on the wheel mass distribution, wheel characteristics, and mass-power ratio (Gabriel Filho et al., 2010; Monteiro et al., 2013). This set of interrelationships explains why a tractor cannot use all the power produced by the engine on the drawbar (Russini et al., 2018).

Tractor mass directly influences field performance (Márquez, 1990), being an important parameter to define the aptitude to perform certain tasks (Biondi et al., 1996; Linares et al., 2006). In addition to engine power and transmission system efficiency, the agricultural tractor is characterized by its size and mass (Estrada et al., 2016). Over the years, tractors have become lighter, and the mass-power ratio has been reduced, making these machines increasingly dependent on ballast performance (Schlosser et al., 2005).

According to Neujahr \& Schlosser (2001), the radial construction tire was developed in the mid1940s, with its canvas forming a 90 angle with the rotation axis, while the diagonal tire forms a $45^{\circ}$ angle. Still, according to the authors, the radial model only became part of the agricultural environment from the 1970s, in the United States and in some European countries; in Brazil, it began to be introduced as of 1994. Frantz (2011) states that the placement of double wheels appears as an alternative to improve soilmachine interaction, increasing traction efficiency and a number of other performance parameters.

The introduction of the radial tire in the Brazilian agricultural environment and the use of double wheels require a series of studies on performance for the different working conditions in the country. Thus, this work evaluates the traction performance of an agricultural tractor, using different wheel and tire configurations.

\section{Materials and methods}

The experiment was conducted in a sandy dystrophic Red Argisol (20.15\% coarse sand; $2.63 \%$ fine sand; $52.65 \%$ silt; and $24.57 \%$ clay), in an area of the Department of Phytosanitary Defense, Federal University of Santa Maria, Rio Grande do Sul State. The climate is type Cfa (Peel et al., 2007). The annual average temperature is $19.2^{\circ} \mathrm{C}$, and the average annual rainfall is $1,708 \mathrm{~mm}$ (Maluf, 2000). The relief is flat with a slope of $2^{\circ}$. Soil water content is $0.31 \mathrm{~kg} \mathrm{~kg}^{-1}$, and the soil cover is composed of black oats (Avena strigosa). For determination of the dry matter index, the equivalent of an area of $1 \mathrm{~m}^{2}$ was obtained, reaching $3,000 \mathrm{~kg} \mathrm{ha}^{-1}$.

The agricultural tractor used was a Massey Ferguson, model MF 6713R Dyna-4, denominated "test tractor", equipped with a four-stroke, four-cylinder AGCO Power diesel engine, model 44DTIC2, with 142 $\mathrm{h}$ of use, displacement of $4,400 \mathrm{~cm}^{3}$, and supercharged suction air. The engine is equipped with a rotary-type mechanicalfuel injection pump, Delphi brand. The dynamometer test showed a maximum engine power of $92.4 \mathrm{~kW}(125.6 \mathrm{hp})$ at 2,100 rpm, according to DIN 70020.

A Massey Ferguson model MF 7219 brake tractor, with 50 hours of use and maximum engine power of $122.7 \mathrm{~kW}(166.8 \mathrm{hp})$ at 1,950 rpm, was used to impose controlled loads on the traction drawbar, according to the dynamometer test. The tractor had a total mass of $98.49 \mathrm{kN}(10,040 \mathrm{~kg})$, with static mass distribution of $56 \%$ on the rear axle and $44 \%$ on the front axle. It is noteworthy that $8.67 \mathrm{kN}(884 \mathrm{~kg})$ corresponded to metallic ballast. The schematic representation of the experiment is shown in Figure 1.

A trifactorial experiment was considered, in which the factors evaluated were: wheel and tire configuration (two levels); mass-power ratio (three levels); and partial loads imposed on the drawbar of the test tractor (three levels). The experimental design was a randomized block with three replicates, totalizing 54 experimental units. For each treatment, a plot with the following dimensions was used: $3.5 \mathrm{~m}$ width and $50 \mathrm{~m}$ length. At the ends of each plot there was a space of $20 \mathrm{~m}$ in length for maneuvers and stabilization of the test tractor and brake tractor.

For setting the wheel and tire configuration, first the test tractor was evaluated with $\mathrm{R}-1 \mathrm{~W}$ tires of radial construction, with the following dimensions: 480/65 R28 front tires and 600/65 R38 TM 800 rear tires, both of Trelleborg brand, making up the simple wheel configuration. Subsequently, R-1 tires of diagonal construction, Goodyear brand, were used as follows: 14.9-28 front tires and 18.4-38 Dyna Torque II rear tires, the latter characterizing the double wheel configuration. According to Márquez (2012), for a soft soil, each type of tire has an ideal slippage: from 18 to $20 \%$ for diagonal tires, and about $15 \%$ for radial tires, corresponding to maximum traction efficiency, slightly higher for radial tires.

For mass-power ratios, the determination of the contact area of the tire with the soil was given by the direct method described by Frantz (2011). The test tractor was placed on the soil and the contour of all tires was marked with white lime to delimit prints on the soil. The internal area not reached by the lime corresponded to the area effectively in contact with the soil. Once this was done, two graduated sets were placed in the smallest and largest axis. The contact area was obtained based on the calculation of the ellipse area, by means of Equation 1.

$A_{e l i}=b \times L \times \beta$

Wherein: $A_{\text {eli }}$ is the contact area of the tire with the soil $\left(\mathrm{cm}^{2}\right), \mathrm{b}$ is the width of the ellipse $(\mathrm{cm}), \mathrm{L}$ is the length of the ellipse $(\mathrm{cm})$, and $\beta$ is the ellipticity coefficient ( $\pi / 4)$.

Mass-power ratios were established based on the study carried out by Estrada et al. (2016); obtained by means of various weighing procedures in a portable scale, Toledo brand, model BPV-830, with capacity for $294.30 \mathrm{kN}(30,000 \mathrm{~kg})$. To reach the three levels of mass-power ratio, the quantities and the positioning of 
the metallic masses (ballasts) of the test tractor were changed, considering about $40 \%$ total mass on the front axle and $60 \%$ on the rear axle. The final mass of the test tractor was $6,020 \mathrm{~kg}$ for the mass-power ratio of $61 \mathrm{~kg} \mathrm{~kW}^{-1} ; 6,610 \mathrm{~kg}$ for theratio of $67 \mathrm{~kg} \mathrm{~kW}^{-1}$; and
$7,320 \mathrm{~kg}$ for the ratio of $74 \mathrm{~kg} \mathrm{~kW}^{-1}$. These values were higher than those found by Schlosser et al. (2005), who recommend a mass-power ratio of around $60 \mathrm{~kg} \mathrm{~kW}^{-1}$ for agricultural operations with higher traction force requirements.

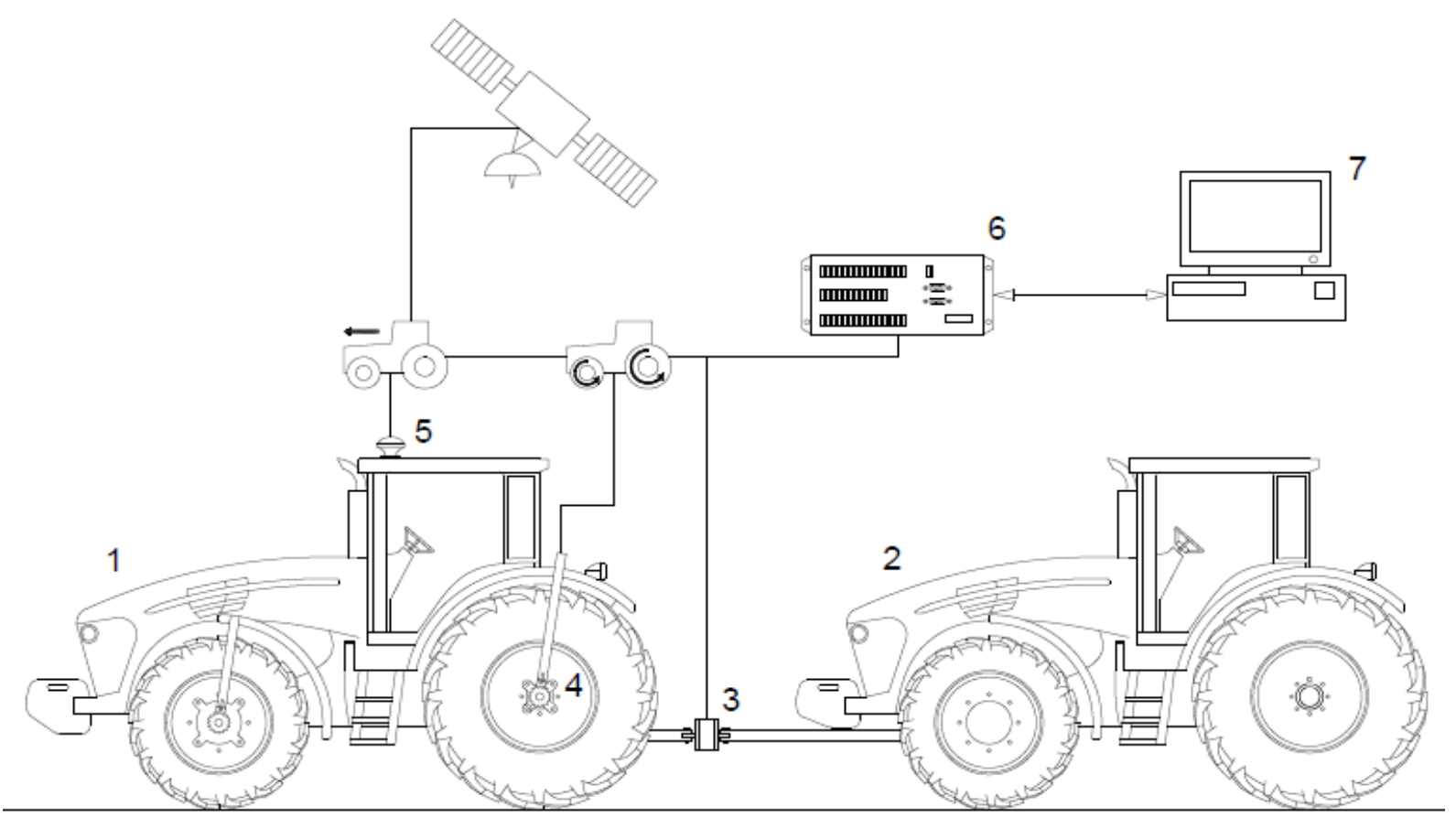

Figure 1 - Schematic representation of the experiment (1. test tractor, 2. brake tractor, 3. load cell, 4. inductive sensor, 5. GPS, 6. central for data acquisition, 7. software for data collection and analysis).

The partial loads applied to the test tractor were obtained from previous field tests, with $48.29 \mathrm{kN}$ $(4,923 \mathrm{kgf})$ as the traction force (Q0) corresponding to the maximum drawbar power of the test tractor, using the double wheel and diagonal tire configuration. From this value, the three partial loads were determined: $24 \mathrm{kN}$ (2,462 kgf); $27 \mathrm{kN}$ (2,708 kgf); and $36 \mathrm{kN}$ (3,692 kgf), corresponding to 35,55 and $75 \%$ of Q0. These loads were imposed by altering the working gear and engine speed of the brake tractor, which was pulled under constant load by the test tractor for a distance of $50 \mathrm{~m}$.

The theoretical travel speed of the test tractor was fixed at $5.60 \mathrm{~km} \mathrm{~h}^{-1}$, obtained at $1,920 \mathrm{rpm}$ for gear $2 \mathrm{~B}$. The internal pressure of the front and rear tires followed the manufacturers' recommendations, being of $179.26 \mathrm{kPa}$ (26 psi) for diagonal tires and $158.58 \mathrm{kPa}(23 \mathrm{psi})$ for radial tires. During the evaluations, the auxiliary front wheel drive and the rear differential lock were permanently driven. In addition, the tractors were always driven by the same operators.

To determine tractor performance, the electronic instrumentation developed by Russini (2009) was used, being represented schematically in Figure 1 . From this instrumentation, values of traction force, driving wheel slipping, and volumetric fuel consumption were obtained. With the obtained data, the dynamic traction coefficient (Equation 2) and traction efficiency (Equation 3) were indirectly calculated, complementing the evaluated variables.

$$
\begin{aligned}
& \mathrm{dtc}=\left(\frac{T F}{A M}\right) \times 100 \\
& T E=\left(\frac{N_{D}}{N_{m}}\right) \times 100
\end{aligned}
$$

Wherein: dtc is the dynamic traction coefficient (\%), TF is the traction force $(\mathrm{kN})$, AM is the adhering mass of the tractor $(\mathrm{kN})$, TE is the traction efficiency (\%), $N_{D}$ is the drawbar power $(\mathrm{kW})$, and $\mathrm{N}_{\mathrm{m}}$ is the engine power (kW).

Data were analyzed for their normality and homoscedasticity by the Bartlett test. The variables were submitted to analysis of variance $(p \leq 0.05)$ and, when significant, the means were analyzed by the Tukey test $(p \leq 0.05)$.

\section{Results and discussion}

After analysis of variance (ANOVA) of the results of traction force, drawbar power, slipping, and specific fuel consumption for the two wheel and tire configurations evaluated (Factor $\mathrm{T}$ ) for the different mass-power ratios (Factor $\mathrm{R}$ ) and partial loads imposed (Factor $\mathrm{L}$ ), it was verified that the afore mentioned variables showed significant variation (Table 1). 
Table 1 - Summary of the ANOVA for the traction force $(\mathrm{kN})$, drawbar power $(\mathrm{kW})$, slipping $(\%)$ and specific fuel consumption $\left(\mathrm{g} \mathrm{kW} \mathrm{h}^{-1}\right)$ parameters.

\begin{tabular}{|c|c|c|c|c|c|}
\hline \multirow[b]{2}{*}{$\begin{array}{l}\text { Sources } \\
\text { of variation }\end{array}$} & \multirow{2}{*}{$\begin{array}{c}\text { Freedom } \\
\text { degrees }\end{array}$} & \multicolumn{4}{|c|}{ Average squares } \\
\hline & & Traction force & Drawbar power & Slipping & $\begin{array}{l}\text { Specific fuel } \\
\text { consumption }\end{array}$ \\
\hline Tire $(T)$ & 1 & 23.46 & 15.64 & 47.15 & 7566.71 \\
\hline Mass-power ratio $(R)$ & 2 & 12.90 & 9.27 & 25.63 & 8737.60 \\
\hline Load (L) & 2 & 746.39 & 856.59 & 624.61 & 19027.97 \\
\hline$T \times R$ & 2 & 7.74 & 15.61 & 3.05 & 24886.97 \\
\hline$T \times L$ & 2 & 3.00 & 0.84 & 9.96 & 1494.63 \\
\hline$R \times L$ & 4 & 5.23 & 1.60 & 18.81 & 1758.69 \\
\hline$T \times R \times L$ & 4 & $2.23^{*}$ & $3.20^{*}$ & $6.09^{\star}$ & $220.00^{*}$ \\
\hline Residue & 36 & 0.40 & 0.92 & 0.77 & 240.49 \\
\hline $\mathrm{Fc}(T \times R \times L)$ & & 5.54 & 3.47 & 7.94 & 0.92 \\
\hline CV (\%) & & 3.32 & 3.77 & 6.60 & 6.63 \\
\hline General mean & & 19.13 & 25.43 & 13.27 & 233.89 \\
\hline
\end{tabular}

${ }^{*}$ Differ statistically $(p \leq 0.05)$.

By observing Table 2, it can be seen that the average values of traction force are lower than the partial loads imposed by the brake tractor. This is due to the limitation of the imposed partial loads them- selves, since they do not promote sufficient wheelground interaction to obtain mean traction force values equal to or greater than the loads imposed on the drawbar.

Table 2 - Tractor performance parameters (traction force, drawbar power, sliding and specific fuel consumption) in the different wheel and tire configurations, for the three mass/power ratios and evaluated loads.

\begin{tabular}{|c|c|c|c|c|c|c|c|c|}
\hline \multirow{2}{*}{$\mathrm{kg} \mathrm{kW}^{-1}$} & \multicolumn{3}{|c|}{ Double Diagonal (DD) } & \multicolumn{3}{|c|}{ Simple Radial (SR) } & \multirow{2}{*}{$\begin{array}{l}\text { DD } \\
\text { Total }\end{array}$} & \multirow{2}{*}{$\begin{array}{c}\text { SR } \\
\text { Total }\end{array}$} \\
\hline & $24 \mathrm{kN}$ & $27 \mathrm{kN}$ & $36 \mathrm{kN}$ & $24 \mathrm{kN}$ & $27 \mathrm{kN}$ & $36 \mathrm{kN}$ & & \\
\hline \multicolumn{9}{|c|}{ Traction force $(\mathrm{kN})$} \\
\hline 61 & $12.78 \mathrm{a}$ & $19.90 \mathrm{a}$ & $28.09 \mathrm{a}$ & $12.37 \mathrm{a}$ & $18.76 \mathrm{a}$ & $25.74 \mathrm{a}$ & $20.26 \mathrm{~b}$ & $8.96 \mathrm{a}$ \\
\hline 67 & $34 \mathrm{a}$ & 20.2 & $28.73 \mathrm{a}$ & $12.18 \mathrm{a}$ & 18.6 & 24.1 & & $2 \mathrm{~b}$ \\
\hline 74 & a & 17.9 & $23.33 \mathrm{~b}$ & $11.99 \mathrm{a}$ & $18.86 \mathrm{a}$ & $23.59 \mathrm{~b}$ & $18.16 \mathrm{c}$ & $8.15 b$ \\
\hline \multicolumn{9}{|c|}{ Drawbar power (kW) } \\
\hline 61 & $18.44 \mathrm{a}$ & $26.73 \mathrm{a}$ & $32.56 \mathrm{~b}$ & $17.83 \mathrm{a}$ & $25.45 \mathrm{a}$ & $32.48 \mathrm{a}$ & $25 . \varsigma$ & $25.26 \mathrm{a}$ \\
\hline 67 & $19.92 \mathrm{a}$ & $27.46 \mathrm{a}$ & $35.49 \mathrm{a}$ & $17.61 \mathrm{a}$ & $25.21 \mathrm{a}$ & $30.71 \mathrm{a}$ & $27.62 \mathrm{a}$ & $24.51 \mathrm{a}$ \\
\hline 74 & $18.73 \mathrm{a}$ & $24.19 b$ & $30.24 \mathrm{c}$ & $\begin{array}{c}17.54 \mathrm{a} \\
\text { Slippina (\%) }\end{array}$ & $25.97 \mathrm{a}$ & $31.26 \mathrm{a}$ & $24.39 c$ & $24.92 \mathrm{a}$ \\
\hline 6 & $7.43 \mathrm{a}$ & $13 . \varepsilon$ & $25.61 \mathrm{a}$ & $7.49 \mathrm{a}$ & $12.95 \mathrm{a}$ & $19.01 \mathrm{a}$ & 15. & $13.15 \mathrm{a}$ \\
\hline 67 & $7.66 \mathrm{a}$ & $13.19 \mathrm{a}$ & $20.74 \mathrm{~b}$ & $7.25 \mathrm{a}$ & $13.13 \mathrm{a}$ & $18.42 \mathrm{a}$ & $13.86 \mathrm{~b}$ & $12.93 \mathrm{a}$ \\
\hline 74 & $8.97 \mathrm{a}$ & $13.55 \mathrm{a}$ & $16.82 \mathrm{c}$ & $6.12 \mathrm{a}$ & $11.65 \mathrm{a}$ & $14.97 \mathrm{~b}$ & $13.11 \mathrm{~b}$ & $10.91 \mathrm{~b}$ \\
\hline \multicolumn{9}{|c|}{ Specific fuel consumption $\left(\mathrm{g} \mathrm{kW} \mathrm{h}^{-1}\right)$} \\
\hline 61 & $0.50 \mathrm{a}$ & 266. & $280.72 \mathrm{a}$ & $239.11 \mathrm{a}$ & $180.27 b$ & $189.04 \mathrm{a}$ & $30 s$ & $202.81 b$ \\
\hline 67 & $217.79 \mathrm{c}$ & $188.36 \mathrm{c}$ & $172.70 \mathrm{~b}$ & $247.50 \mathrm{a}$ & $230.05 a$ & $214.96 \mathrm{a}$ & $192.95 \mathrm{c}$ & $230.84 a$ \\
\hline 74 & $281.93 \mathrm{~b}$ & $225.58 \mathrm{~b}$ & $197.87 \mathrm{~b}$ & $259.45 \mathrm{a}$ & $229.46 \mathrm{a}$ & $208.64 \mathrm{a}$ & $235.13 \mathrm{~b}$ & $232.52 \mathrm{a}$ \\
\hline
\end{tabular}

${ }^{*}$ Means followed by the same letter in the column do not differ by the Tukey test at $5 \%$ error probability.

In the double wheel and diagonal tire configuration, when considering the average value of partial loads, traction force differed for all mass-power ratios. For the simple wheel and radial tire configuration, in turn, this variable differed only for the mass-power ratio of $61 \mathrm{~kg} \mathrm{~kW}^{-1}$. Traction force values were higher for double wheel and diagonal tire compared to single wheel and radial tire configuration, even though the contact area of the latter $\left(4.956 \mathrm{~cm}^{2}\right)$ was $17.84 \%$ higher when compared to the first $\left(4,071.85 \mathrm{~cm}^{2}\right)$.

This behavior is due to the increased pressure exerted by the wheel on the soil, given the smaller area of contact, which, in good traffic conditions, makes the double wheel and diagonal tire have greater grip and, consequently, develop greater traction force for the same mass-power ratio. For heavy operations, Schlosser et al. (2005) warn of the need to add ballast in high-power tractors with low mass-power ratio.

The soil cover type may also influence the result, since representative values of dry matter were observed.The double wheel and diagonal tire configuration allowed for a higher traction capacity, due to the greater pressure exerted on the soil. The application of dynamic loads on ground wheels produces tension at the soil-tire interface both at surface and at depth, which affect soil compaction and traction development (Horn \& Lebert, 1994).

For double wheels and diagonal tires with the 
same internal pressure, there is a better distribution of the tire on the soil, with an increased contact area (Frantz, 2011). This provides higher traction force values in relation to single wheels and diagonal tires. In general, for both wheel and tire configurations evaluated in this study, the lowest traction force values were obtained with the highest mass-power ratio $\left(74 \mathrm{~kg} \mathrm{~kW}^{-1}\right)$. This is due to increased rolling resistance and the approximation of the critical travel speed, that is, the minimum working travel speed for the tractor to use all engine power as a function of its mass, as described by Russini et al. (2018), emphasizing the tendency to decrease driving wheel slipping.

From this result, it can be inferred that under the conditions of this experiment, the dynamic traction coefficient, obtained from the relationship between traction force and adhering mass, was higher for the lowest mass-power ratio, with a value of $34.30 \%$ for the double wheel and diagonal tire configuration, and $32.10 \%$ for the simple wheel and radial tire configuration. This value decreases as the mass-power ratio increases, reaching $25.28 \%$ and $25.27 \%$, respectively, for the double wheel and diagonal tire configuration and the single wheel and radial tire configuration. In the experiment, the partial loads applied were lower than the maximum load (Q0), but the latter shows a dynamic traction coefficient of $49 \%$, similar to that proposed by Márquez (2012).

For the average values of drawbar power, we can observe the same behavior found for traction force (Table 2). The value for the double wheel and diagonal tire configuration with the partial load of $36 \mathrm{kN}$ and mass-power ratio of $67 \mathrm{~kg} \mathrm{~kW}^{-1}$ was $15.56 \%$ higher when compared to the simple wheel and radial tire configuration $(30.71 \mathrm{~kW})$, for the same setting. When evaluating the performance of a tractor with diagonal and radial tires, using different working gears and ballast conditions, Monteiro et al. (2011) did not observe a difference between the construction types of tires and liquid ballast variations.

The highest traction power obtained in the single wheel and radial tire configuration was 32.48 $\mathrm{kW}$, less than half a percent lower than that observed in the double wheel and diagonal tire configuration, for the same applied load (36 kN) and mass-power ratio $\left(61 \mathrm{~kg} \mathrm{~kW}^{-1}\right)$, not differing from other partial loads and mass-power ratios (Table 2). These values represent an efficiency of about $35 \%$ in transforming engine power into traction power. For the surface condition evaluated, the values are lower than those proposed by Márquez (2012) (68\%), since the partial loads imposed on the test tractor are inferior to the traction force (Q0) corresponding to maximum drawbar power.

Regarding driving wheel slipping values, both wheel and tire configurations were within acceptable values. According to Neujahr \& Schlosser (2001), slipping values between 5 and $20 \%$ promote the highest traction efficiency. It is observed that the smallest slipping values do not coincide with the highest traction force values; similar result was obtained by
Russini et al. (2018).

The best slipping performance was verified for the simple wheel and radial tire configuration, both as a function of the variation in the partial loads applied and regarding mass-power ratios. This result agrees with Monteiro et al. (2011); when evaluating agricultural tractor performance, the authors observed lower slipping values for radial tires with $40 \%$ water ballast compared to diagonal tires.

The lowest specific consumption values correspond to the highest drawbar power and efficiency; the same behavior was observed by Monteiro et al. (2011). The lowest specific consumption value for the different partial loads was observed in the double wheel and diagonal tire configuration with the masspower ratio of $67 \mathrm{~kg} \mathrm{~kW}^{-1}$ (192.95 $\mathrm{g} \mathrm{kW} \mathrm{h}^{-1}$ ), differing from other configurations. For the simple wheel and radial tire condition, in turn, the lowest specific consumption value (202.81 $\mathrm{g} \mathrm{kW} \mathrm{h}^{-1}$ ) was obtained with the mass-power ratio of $61 \mathrm{~kg} \mathrm{~kW}^{-1}$, differing from the others. The higher the value of specific fuel consumption, the lower the energy conversion efficiency (Salvador et al., 2009).

\section{Conclusions}

The double wheel and diagonal tire configuration should be used, since it showed the best traction performance (traction force, traction power, and traction efficiency) when compared to the simple wheel and radial tire configuration, for the conditions of this experiment.

The smallest slipping values were observed for the simple wheel and radial tire configuration.

The lowest specific fuel consumption values were observed with the mass-power ratio of $67 \mathrm{~kg} \mathrm{~kW}^{-1}$ for the double wheel and diagonal tire configuration, and $61 \mathrm{~kg} \mathrm{~kW}^{-1}$ for the simple wheel and radial tire configuration.

\section{Acknowledgements}

The authors are grateful to the National Council for Scientific and Technological Development (CNPq) for the productivity scholarship granted to the second author; and to Your Agriculture Company (AGCO do Brasil) for providing the brake tractor and the agricultural wheels and tires used in this work.

\section{References}

Biondi P, Maraziti F, Monarca D (1996) Technical trends of tractors and combines (1960-1989) based on Italian type-approval data. Journal of Agricultural Engineering Research 65(1):1-14.

Estrada JS, Schlosser JF, Farias MS, Martini AT, Santos GO (2016) Mass of agricultural tractors available in the brazilian market. Ciência Rural 46(8):1390-1394 . 
Fiorese DA, Marasca I, Fernandes BB, Sandi J, Morelli-Ferreira F, Lanças KP (2015) Desempenho de três tratores agrícolas em ensaios de tração. Revista de Agricultura Neotropical 2(2):68-76.

Frantz UG (2011) Análise de desempenho em tração de rodado simples e duplo em um trator agrícola. UFSM (Dissertação de mestrado em Engenharia Agrícola).

Gabriel Filho A, Monteiro LA, Lanças KP, Guerra SPS, Jesuino PR (2010) Influência da altura das garras dos pneus de um trator em área de plantio direto. Revista Brasileira de Engenharia Agrícola e Ambiental 14(10):1123-1128.

Horn R, Lebert M (1994) Soil compactability and compressibility. In: Soane BD, Ouwerkerk CV Soil compaction in crop production, developments in agricultural engineering 1st edn, Elsevier. p.45-69.

Jasper SP, Bueno LSR, Laskoski M, Langhinotti CW, Parize GL (2016) Desempenho do trator de 157 kW na condição manual e automático de gerenciamento de marchas. Revista Scientia Agraria 17(3):55-60.

Linares P, Catalán H, Méndez V (2006) Teoría de la tracción de tractores agrícolas. ETSIA. 215p.

Maluf JRT (2000) Nova classificação climática do estado do Rio Grande do Sul. Revista Brasileira de Agrometeorologia 8(1):141-150.

Márquez L (1990) Solo Tractor'90. Laboreo. 231p.

Márquez $L$ (2012) Tractores agrícolas: tecnología y utilización. B\&H Grupo Editorial. 844p.

Monteiro LA, Lanças KP, Guerra SPS (2011) Desempenho de um trator agrícola equipado com pneus radiais e diagonais com três níveis de lastros líquidos. Revista Engenharia Agrícola 31(3):551-560.

Monteiro LA, Albiero D, Souza FH, Melo RP, Cordeiro IM (2013) Rendimento na barra de tração de um trator agrícola com diferentes relações de peso e potência. Revista Ciência Agronômica 44(1):70-75.
Neujahr EB, Schlosser JF (2001) Comportamento de pneus agrícolas radiais e diagonais em relação à tração. Engenharia Agrícola 21(2):180-189.

Peel MC, Finlayson BL, McMahon TA (2007) Updated world map of the Köppen-Geiger climate classification. Hydrology and Earth System Sciences 11(5):16331644.

Peloia PR, Milan M (2010) Proposta de um sistema de medição de desempenho aplicado à mecanização agrícola. Engenharia Agrícola 30(4):681-691.

Russini A (2009) Projeto, construção e teste de instrumentação eletrônica para avaliação do desempenho de tratores agrícolas. UFSM (Dissertação de mestrado em Engenharia Agrícola).

Russini A, Schlosser JF, Farias MS (2018) Estimation of the traction power of agricultural tractors from dynamometric test. Ciência Rural 48(4):1-7.

Salvador N, Mion RL, Benez SH (2009) Consumo de combustível em diferentes sistemas de preparo periódico realizados antes e depois da operação de subsolagem. Ciência e Agrotecnologia 33(3):870-874.

Schlosser JF, Debiasi H, Willes JA, Machado ODC (2005) Análise comparativa do peso específico dos tratores agrícolas fabricados no Brasil e seus efeitos sobre a seleção e uso. Ciência Rural 35(1):92-97.

Toledo A, Furlani CEA, Silva RP, Lopes A, Dabdoub MJ (2010) Comportamento espacial da demanda energética em semeadura de amendoim em Latossolo sob preparo convencional. Engenharia Agrícola 12(30):459-467.

Zoz FM, Grisso RD (2003) Traction and tractor performance. ASAE. 46p.

Yavuzcan HG, Matthies D, Auernhammer H (2005) Vulnerability of Bavarian silty loam soil to compaction under heavy wheel traffic: impacts of tillage method and soil water content. Soil and Tillage Research 84(2):200-2015. 